vende grønlandske forekomster til eventuel produktion af facade- og gravsten.

Glaciologiske undersøgelser blev gennemført flere steder i Vestgrønland, primært med henblik på udnyttelse af vandkraft, men også som et dansk/grønlandsk bidrag til den internationale klimaforskning. Unders $\varnothing$ gelserne ved Tasersiaq syd for Søndre Strømfjord afsluttedes efter 10 års indsamling af massebalancedata. Studier af forholdene nord for Ilulissat blev videreført i samarbejde med internationale forskningsgrupper. I Buksefjordsområdet ved Nuuk udvidedes de glacio- logiske undersøgelser til de sydlige dele af vandkraftområdet.

I 1990 har GGU udgivet to geologiske kort fra henholdsvis Sydøstgrønland og Nordgrønland og tre kortbladsbeskrivelser til tidligere publicerede kort. I egne serier er desuden udkommet en bulletin, tre rapporter samt ni bidrag i Open File-serien og et i Thematic Map-serien. Som resultat af GGU-aktiviteter er der publiceret 54 artikler i internationale fagtidsskrifter (se s. 66).

\title{
Review of the Survey's activities in 1990
}

\author{
Martin Ghisler
}

Director

Negotiations on a new strategy for exploration and utilisation of the mineral resources in Greenland were started during the year between the Greenland Home Rule Authorities and the Danish state. This strategy aims to encourage the mining and oil industry to intensify exploration activities in Greenland. In connection with this new approach, the Geological Survey of Greenland (Grønlands Geologiske Undersøgelse, GGU) has continued and developed initiatives to facilitate ready access to relevant geological, geophysical and geochemical data held by the Survey. Emphasis has been placed on the following:

- enhancement of a number of existing geological data bases, including the addition of data covering West Greenland to the Mineralization Data Bank;

- completion of the drill core storage facility in Copenhagen, containing material from earlier mining and exploration activities;

- publication of the first issue of a new thematic map series, comprising 57 digitalised maps of the NuukManiitsoq area of West Greenland;

- introduction of a new information service for the oil industry with publication of a biannual newsletter (GHEXIS).

Field projects in 1990 were carried out with a total of 43 participants. The largest group worked from a base west of Danmarkshavn in North-East Greenland, and completed a three year programme of activity in the region between $75^{\circ}$ and $78^{\circ} \mathrm{N}$. Studies included geol- ogical mapping, geochemical sampling, and glaciology and Quaternary geology. An evaluation of the hydrocarbon potential between latitudes $72^{\circ}$ and $75^{\circ} \mathrm{N}$ in North-East Greenland, based on field work in 1986-89, was also concluded.

Geological reconnaissance on Nuussuaq in West Greenland identified targets for sedimentological, palynological and source rock studies planned for 1991 and 1992. Systematic stream sediment sampling was undertaken in the area west and north of Søndre Strømfjord. Geochemical sampling took place north of Maarmorilik, including continued work on earlier identified gold anomalies.

A seismic acquisition programme on the southern part of the West Greenland shelf between latitudes $62^{\circ}$ and $70^{\circ}$ yielded significant new data (3285 line kilometres). In addition reprocessing of $2670 \mathrm{~km}$ of reflection seismic data from the Labrador Sea acquired in 1977 was undertaken.

Glacier hydrological studies and hot water drilling north of Jakobshavn contribute valuable information to hydropower development studies, as well as contributing to international research on climatic change. Mass-balance studies were terminated at Tasersiaq near Søndre Strømfjord after 10 years of continuous measurements. Collection of glacier-hydrological data was continued south of Buksefjorden, where Greenland's first hydropower station is under construction.

GGU participated in a field and laboratory study 
initiated by the Greenland Home Rule Administration designed to evaluate the exploitation potential for ornamental stones in West and South Greenland.

GGU has continued to assist the Mineral Resources Administration for Greenland with inspection and evaluation of activities by concessionaires. Exploitation at the Black Angel lead-zinc mine at Maarmorilik was terminated mid-summer 1990 after 17 years of production. In East Greenland GGU made inspection visits to the mineral exploration activities in progress following the discoveries of stratabound gold and platinum group metals in the Skaergaard and Kap Edvard Holm intrusions. On the hydrocarbon side, GGU has prepared an evaluation of the hydrocarbon potential of the Jame- son Land basin, based on both GGU and company data, following the announcement that ARCO/AGIP would relinquish their concession at the end of 1990.

During the year the 1:500 000 geological map sheet 'Skjoldungen' and the 1:1 million Quaternary geological map sheet 'Hall Land - Nansen Land' were printed. Three reports, one bulletin and three map sheet descriptions were published, together with nine contributions to the Open File Series and one to the new Thematic Map Series. As a result of GGU activities, 54 papers were published in international scientific journals in 1990; these are listed together with GGU's own publications at the end of the Report of Activities. 